\title{
New records of lichens and allied fungi from the Leningrad Region, Russia. V
}

\section{Dmitry E. Himelbrant ${ }^{1,2}$, Jurga Motiejūnaité $\dot{3}^{3}$ Irina S. Stepanchikova ${ }^{1,2} \&$ Gulnara M. Tagirdzhanova ${ }^{1}$}

\author{
${ }^{1}$ Department of Botany, St. Petersburg State University, Universitetskaya emb. 7/9, 199034 St. Petersburg, Russia. \\ E-mails: d_brant@mail.ru, stepa_ir@mail.ru, felis.murgul@gmail.com \\ ${ }^{2}$ Laboratory of Lichenology and Bryology, Komarov Botanical Institute RAS, \\ Professor Popov St. 2, 197376 St. Petersburg, Russia. \\ ${ }^{3}$ Laboratory of Mycology, Nature Research Centre, Institute of Botany, Žaliųjų Ežerų 49, LT-08406 Vilnius, Lithuania. \\ E-mail: jurga.motiejunaite@botanika.lt
}

\begin{abstract}
Eight species of lichens and seven lichenicolous fungi are reported from the Leningrad Region. Agonimia repleta, Protoparmelia hypotremella and Stereocaulon taeniarum are reported for the first time for Russia; Clypeococcum cetrariae is new to the European Russia; Lepraria nivalis, Merismatium aff. nigritellum (on Physcia aipolia) and Stigmidium leprariae are new to the North-Western European Russia; Cladonia macroceras, C. strepsilis, Endococcus fusiger, Lichenoconium erodens, Lobothallia melanaspis, Niesslia cladoniicola and Skyttella mulleri are new to the Leningrad Region; Sclerophora coniophaea is new to Saint Petersburg. The most noteworthy records are briefly discussed.
\end{abstract}

\section{INTRODUCTION}

This paper is next in the series of publications on new records of lichens and allied fungi in the Leningrad Region and Saint Petersburg (Kuznetsova et al., 2007; Stepanchikova et al., 2009, 2010, 2011a,b; Kuznetsova et al., 2012; Pykälä et al., 2012; Himelbrant et al., 2013) to contribute to the knowledge on the regional lichen flora. Among the 15 taxa, several are recorded for the first time in Saint Petersburg or Leningrad Region, others are new for the NorthWestern European Russia, European Russia or Russian Federation.

\section{MATERIAL AND METHODS}

The materials were collected mainly in the period of 2011-2013 in the Eastern and Western Leningrad Region or Saint Petersburg (ELR, WLR, SPb respectively) and were deposited in the lichen herbaria of Saint Petersburg State University (LECB), Nature Research Centre, Institute of Botany in Vilnius (BILAS) and Botanical Museum of University of Helsinki (H). Most specimens of lichenicolous fungi were identified by J. Motiejūnaite, lichens and Clypeococcum cetrariae by D. Himelbrant, I. Stepanchikova and G. Tagirdzhanova. Lichen substances in the thalli of Protoparmelia hypotremella and Stereocaulon taeniarum were analyzed by using the standard technique of high performance thin-layer chromatography (HPTLC) in solvent systems A, B and C (Orange et al., 2001). The illustrations of Clypeococcum cetrariae and Protoparmelia hypotremella were made by using a Carl Zeiss STEMI-2000 CS dissecting microscope with an AxioCam ICc 3 camera and light microscope Carl Zeiss Axioskop 40 with camera QImaging MicroPublisher 5.0 RTV. Brief discussions on the most interesting records (new to NW European Russia, European Russia or Russian Federation) are provided.

The names of the main collectors in the species list are abbreviated as follows: DH - Dmitry E. Himelbrant, GT - Gulnara M. Tagirdzhanova, IS - Irina S. Stepanchikova. The subdivision of the Leningrad Region (LR) was published in our previous paper (Stepanchikova et al., 2010). The biogeographical provinces of Eastern Fennoscandia are abbreviated traditionally (Kotiranta et al., 1998): Ik - Isthmus karelicus, $\mathrm{Ka}$ - Karelia australis. Lichenicolous fungi are marked with \#. The nomenclature of taxa follows mainly Nordin et al. (2011).

\section{THE SPECIES}

Agonimia Repleta Czarnota \& Coppins - WLR, Kingisepp District, Kurgal'sky Peninsula, 
Kurgal'sky protected area, NE of Tiskolovo village, seashore slope of the Gulf of Narva, $59^{\circ} 43^{\prime} 20^{\prime \prime} \mathrm{N}, 28^{\circ} 02^{\prime} 05^{\prime \prime} \mathrm{E}$, broadleaved forest on the slope, bark of old Fraxinus excelsior L., 14.04.2007, leg. DH (H). - New to Russia. Distribution in Fennoscandia and Baltic countries: Sweden, Finland (Nordin et al., 2011). This species is characterized by granular to granularverrucose thallus, black pyriform perithecia to $0.2 \mathrm{~mm}$ in diameter with vertical channels at the apical part, 8-spored asci and rather small ascospores not exceeding $50 \mu \mathrm{m}$ at length (Czarnota \& Coppins, 2000).

Cladonia macroceras (Delise) Hav. - WLR, Ka, Vyborg District, the Gulf of Vyborg, Vyborgsky protected area, Mayachny Island, $60^{\circ} 34^{\prime} 24^{\prime \prime} \mathrm{N}$, $28^{\circ} 25^{\prime} 30^{\prime \prime} \mathrm{E}$, moss-lichen community on rocks, on soil, 11.09.2013, leg. DH, IS \& GT (LECB); WLR, Ka, Vyborg District, the Gulf of Vyborg, Vyborgsky protected area, Krasivy Island, $60^{\circ} 32^{\prime} 59^{\prime \prime} \mathrm{N}, 28^{\circ} 34^{\prime} 16^{\prime \prime} \mathrm{E}$, moss-lichen community on rocky outcrops, on soil, 14.09.2013, leg. DH, IS \& GT (LECB); WLR, Ka, Vyborg District, the Gulf of Vyborg, Vyborgsky protected area, Travnik Island, 60³2'50'N, 28 33'57"E, strongly disturbed moss-lichen community on rocky outcrops, on soil, 14.09.2013, leg. DH, IS \& GT (LECB). - New to LR. Reported from LR erroneously by Sokolova (1995) on the base of uncertain record; no specimens present in herbaria. Distribution in North-Western European Russia outside of LR: Republic of Karelia (Fadeeva et al., 2007). Distribution in Fennoscandia and Baltic countries: Norway, Sweden, Finland (Nordin et al., 2011), Estonia (Randlane et al., 2013). The species represents Cladonia gracilis group and is distinguished mainly by shiny, tough, thick cortex of podetia, presence of podetial and primary squamules, as far as inhabiting rocky outcrops or calcareous soil (Ahti \& Stenroos, 2013).

Cladonia strepsilis (Ach.) Grognot - WLR, Luga District, left bank of the Yaschera River, vicinity of the village Yaschera, $1.2 \mathrm{~km} \mathrm{NE}$ of the confluence of the rivers Luga and Yaschera, S slope of small hill, near the sandy road, $58^{\circ} 53^{\prime} 20^{\prime \prime} \mathrm{N}$, $29^{\circ} 49^{\prime} 41^{\prime \prime E}$, open pine forest with lichens, Calluna vulgaris (L.) Hull and mosses, on sandy soil together with Pycnothelia papillaria (Ehrh.) L. M. Dufour, 19.05.2013, leg. DH \& IS (LECB). - New to LR. Distribution in North-Western European Russia outside of LR: Republic of Karelia (Fade- eva et al., 2007). Distribution in Fennoscandia and Baltic countries: Norway, Sweden, Finland (Nordin et al., 2011), Latvia (Piterāns, 2001). Easily recognized with unique $\mathrm{C}+$ blue-green thallus reaction (strepsilin), poorly developed podetia and forming dense cushions of rigid and elongated squamules (Ahti \& Stenroos, 2013).

\# Clypeococcum Cetrariae Hafellner - WLR, Luga District, left bank of the Yaschera River, vicinity of the village Yaschera, $1.2 \mathrm{~km} \mathrm{NE}$ of the confluence of the rivers Luga and Yaschera, S slope of small hill, near the sandy road, $58^{\circ} 53^{\prime} 20^{\prime \prime} \mathrm{N}$, $29^{\circ} 49^{\prime} 41^{\prime \prime} \mathrm{E}$, open pine forest with lichens, Calluna vulgaris and mosses, on thallus of Cetraria islandica (L.) Ach. on sandy soil, 19.05.2013, leg. DH \& IS (LECB). - New to European Russia. Known from Republic of Sakha (Yakutia) (Zhurbenko, 2007b) and Krasnoyarsk Territory (Zhurbenko \& Zhdanov, 2013). Distribution in Fennoscandia and Baltic countries: Estonia (Randlane et al., 2013), Latvia (Motiejūnaite \& Piterāns, 1998), Lithuania (Motiejūnaitè et al., 2011). Lichenicolous fungus, easily recognized by forming visible black clypeus with numerous black pseudothecia, 4-spored asci with oneseptate dark brown verrucose ascospores and growing on thalli of C. islandica (Hafellner, 1994; Zhurbenko \& Zhdanov, 2013) (Fig. 1).

\# Endococcus fusiger Th. Fr. \& Almq. - WLR, Ka, Vyborg District, the Gulf of Vyborg, Vyborgsky protected area, Bol'shoy Lugovoy Island, $60^{\circ} 32^{\prime} 38^{\prime \prime} \mathrm{N}, 28^{\circ} 33^{\prime} 43^{\prime \prime} \mathrm{E}$, seashore black alder forest with bird cherry and Calamagrostis sp., on thallus of Rhizocarpon geminatum Körb. on siliceous bolder, 13.09.2013, leg. DH, IS \& GT (BILAS); WLR, Ka, Vyborg District, the Gulf of Vyborg, Vyborgsky protected area, Travnik Island, 60 $32^{\prime} 44^{\prime \prime} \mathrm{N}, 28^{\circ} 34^{\prime} 00^{\prime \prime} \mathrm{E}$, seashore black alder forest with bird cherry, Convallaria majalis L. and grasses, on thallus of Rhizocarpon reductum Th. Fr. on siliceous boulder, 14.09.2013, leg. DH, IS \& GT (BILAS). - New to LR. Known from different territories of Russia (e. g. Fadeeva et al., 2007; Zhurbenko, 2009b) as a part of E. perpusillus Nyl. complex. Distribution in North-Western European Russia outside of LR: Republic of Karelia (Fadeeva et al., 2007). Distribution in Fennoscandia and Baltic countries: Sweden (Nordin et al., 2011). E. fusiger is a problematic species of a notoriously complicated E. perpusillus complex. It was not 


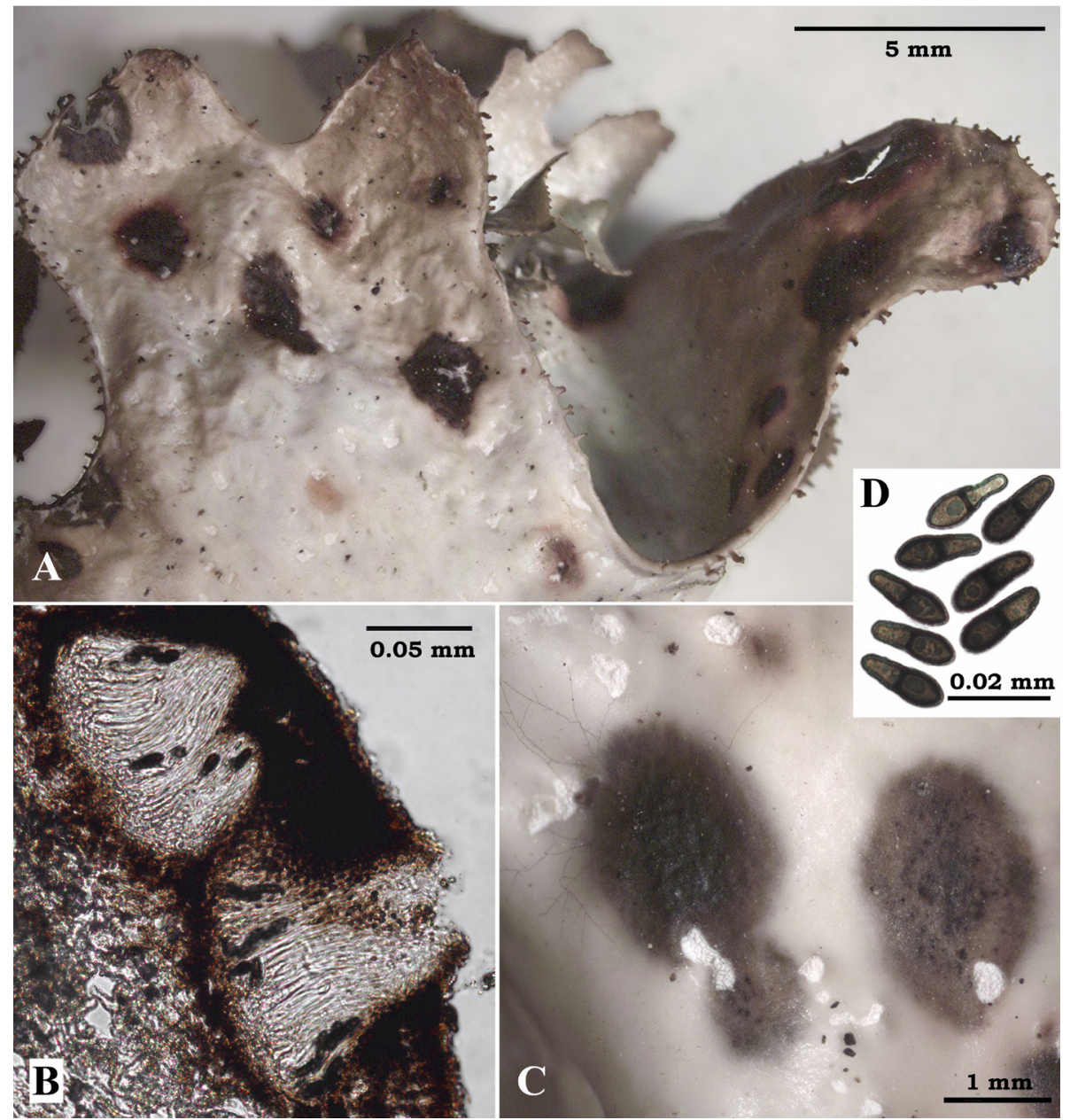

Fig. 1. Clypeococcum cetrariae: A - infected thallus of Cetraria islandica; B - pseudothecia; C clypei with numerous black pseudothecia; D - ascospores.

recognized by Triebel (1989) and Ihlen \& Wedin (2008) who considered it to be conspecific with $E$. perpusillus but Sérusiaux et al. (1999), applying narrower species concept, distinguished three species of Endococcus growing on Rhizocarpon. Of these, E. fusiger is characterised mainly by superficial apothecia. Though Sérusiaux et al. (1999) indicated E. fusiger having spore size 12.5-16 × 6-7 $\mu \mathrm{m}$, though later authors (Kocourková, 2000, Kukwa \& Flakus, 2009) showed that the spores may be longer or narrower and type diagnosis indicates spore size 15-18 × 5-6 $\mu \mathrm{m}$ (according to Kocourková, 2000), however, perithecia are always sessile and rather large. In both our specimens perithecia were always sessile, rather large (150-180 $\mu \mathrm{m}$ diam.), and spores were $12-16 \times 5-6 \mu \mathrm{m}$, slightly narrower than indicated by Sérusiaux et al. (1999).

LEPRARIA NIVALIS J. R. Laundon - SPb, Pushkin District, Ekaterininsky park, Bolshoj Kapriz flag stone hill, $59^{\circ} 42^{\prime} 48^{\prime \prime} \mathrm{N}, 30^{\circ} 22^{\prime} 60^{\prime \prime} \mathrm{E}$, on vertical flag stones, 12.08.2012, leg. IS (LECB). Specimen contains psoromic, protocetraric acids and trace of gyrophoric/lecanoric acid. New to European Russia. Distribution in Russia is still unclear. It was reported from Southern Ural, Southern Siberia and Russian Caucasus (Urbanavichus, 2010; Urbanavichus \& Urbanavichene, 2010). However this data seems to be doubtful because 
the previously published records not based on analysis of lichen substances (see Urbanavichus \& Urbanavichene, 2010 and discussion in Urbanavichene et al., 2013, under Lepraria crassissima). Distribution in Fennoscandia and Baltic countries: Sweden, Finland (Nordin et al., 2011). The species is morphologically very close to L. crassissima (Hue) Lettau, but the later has different chemistry (divaricatic and nordivaricatic acid, zeorin) and ecology: L. nivalis is mostly confined to calcareous substrates while L. crassissima generally prefers siliceous rocks (see Saag et al., 2009).

\# Lichenoconium erodens M. S. Christ. \& D. Hawksw. - WLR, Ka, Vyborg District, the Gulf of Vyborg, Vyborgsky protected area, Bol'shoy Lugovoy Island, 60³2'50"N, 28 33'32" E, birchpine forest with Convallaria majalis, Vaccinium myrtillus L. and mosses, on thallus of Hypogymnia physodes (L.) Nyl. on bark of Sorbus aucuparia L., 13.09.2013, leg. DH, IS \& GT (BILAS). - New to LR. Distribution in North-Western European Russia outside of LR: Republic of Karelia (Zhurbenko \& Himelbrant, 2002; Fadeeva et al., 2007). Distribution in Fennoscandia and Baltic countries: Norway, Sweden, Finland (Nordin et al., 2011), Estonia (Randlane et al., 2013), Latvia (Motiejūnaitè et al., 2006), Lithuania (Motiejūnaité, 1999).

LoBothallia MELANASPIS (Ach.) Hafellner - WLR, Ik, Priozersk District, E of Pyatirech'e village (former Finnish Viisjoki), Ladoga Lake shore, the end of Daleky Cape (former Saunaniemi), stony military mole with fortifications (Saunasaari), $60^{\circ} 34^{\prime} 15^{\prime \prime} \mathrm{N}, 30^{\circ} 41^{\prime} 09^{\prime} \mathrm{E}$, on granite, 05.08.2011, IS \& Ludmila Gagarina (LECB). - New to LR. Distribution in North-Western European Russia outside of LR: Republic of Karelia (Fadeeva et al., 2007). Distribution in Fennoscandia and Baltic countries: Norway, Sweden, Finland (Nordin et al., 2011).

\# Merismatium aff. nigritellum (Nyl.) Vouaux ELR, Tikhvin District, Vepssky Les protected area, ca. $50 \mathrm{~km}$ SSE of Vinnitsy, 60 $133^{\prime} 34^{\prime \prime N}$, $35^{\circ} 08^{\prime} 25^{\prime \prime E}$, on thallus of Physcia aipolia (Ehrh. ex Humb.) Fürnr. on bark of Populus tremula L., 17.08.2012, leg. GT, IS \& Lilia Kuz'mina (BILAS). - New to North-Western European Russia. Known from different territories of Arctic Siberia (Zhurbenko, 2009b). Distribution in
Fennoscandia and Baltic countries: Norway, Sweden, Finland (Nordin et al., 2011).

$M$. nigritellum apparently is a complex of species, originally it was considered to grow only on crustose lichens, especially on muscicolous species (Triebel, 1989), but Etayo and Sancho (2008) found it also on Stereocaulon, and Eichler et al. (2010) indicate Leptogium as a host. According to various authors, the measurements in $M$. nigritellum also show rather wide range: ascomata $150-300 \mu \mathrm{m}$ and ascospores $14-32 \times$ 6.5-15 $\mu \mathrm{m}$. Our specimen, apart from unusual host - P. aipolia, in all other details showed close affinity with $M$. nigritellum: ascomata measured 160-170, ascospores were brown, not constricted at the septa, submuriform (with 4-6 latitudinal and 2-3 longitudinal septa), lacking halo, $18-20 \times 6-8 \mu \mathrm{m}$.

\# Niesslia cladonitcola D. Hawksw. \& W. Gams - WLR, Ik, Vsevolozhsk District, Termolovsky protected area, ca. $4.5 \mathrm{~km} \mathrm{NNW}$ of Elizavetinka village, $60^{\circ} 18^{\prime} 30^{\prime \prime} \mathrm{N}, 30^{\circ} 10^{\prime} 39^{\prime \prime} \mathrm{E}$, birch forest with spruces, Vaccinium myrtillus and Sphagnum spp., on thallus of Cladonia sp. on bark of tree, 09.09.2011, leg. IS \& DH (BILAS). - New to LR. Distribution in North-Western European Russia outside of LR: Republic of Karelia (Fadeeva et al., 2007). Distribution in Fennoscandia and Baltic countries: Sweden, Finland (Nordin et al., 2011), Estonia (Randlane et al., 2013).

PROTOPARMELIA HYPOTREMELla van Herk, Spier \& Wirth - ELR, Volkhov District, W shore of Zagubsky Peninsula between Mel'nichny stream and Cherny cape, $60^{\circ} 28^{\prime} 46-55^{\prime \prime} \mathrm{N}, 32^{\circ} 36^{\prime} 08-23^{\prime \prime} \mathrm{E}$, mixed spruce-maple-lime-black alder forest, on bark of old Tilia cordata Mill., 21.05.2011, leg. DH, IS \& Ekaterina Kuznetsova (LECB). New to Russia. Distribution in Fennoscandia and Baltic countries: Sweden (Nordin et al., 2011). Sterile lichen characterized by grey to pale olivaceous to buff, dull to slightly glossy, granular (sometimes of isidia-like granules) to microsquamulose thallus (Fig. 2), squamules up to $0.6 \mathrm{~mm}$ wide with margins paler than the surface (Aptroot et al., 1997).

Sclerophora CONiophaEa (Norman) Mattsson \& Middelb. - SPb, Kurortny District, Sestroretsk, N part of Dubki Park, 6005'31'N, 2956'03"E, in bark crevices of very old Quercus robur L., 01.06.2013, leg. DH and Ekaterina Kuznetsova 

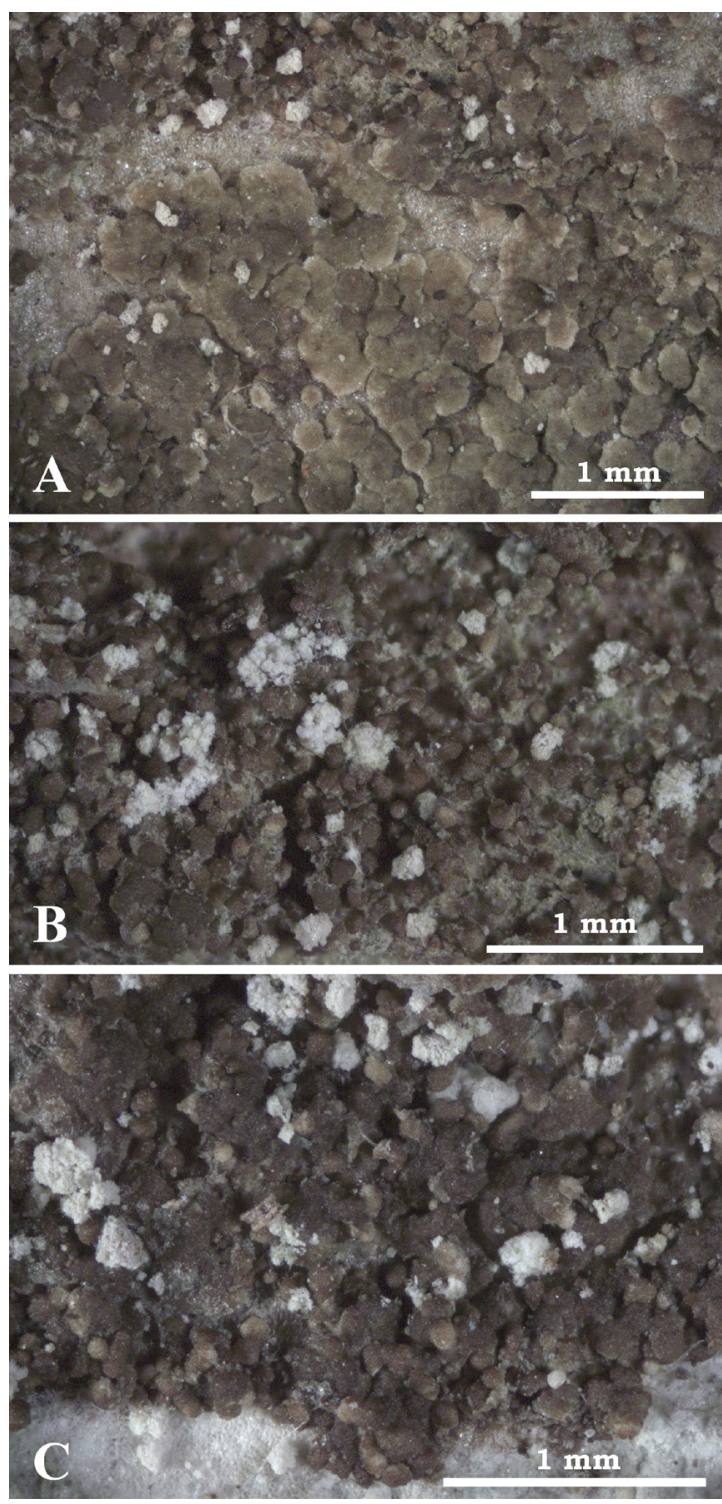

Fig. 2. Protoparmelia hypotremella: A - microsquamulose thallus (brown squamules with paler margins); B, C - isidia-like granules.

(LECB). - New to SPb. Known from ELR (Stepanchikova et al., 2009) and WLR (Stepanchikova et al., 2011b). Distribution in North-Western European Russia outside of LR: Republic of Karelia (Fadeeva et al., 2007). Distribution in Fennoscandia and Baltic countries: Norway, Sweden, Finland (Nordin et al., 2011), Estonia (Randlane et al., 2013), Lithuania (Motiejūnaitè et al., 2004). Indicator of biologically valuable forests in the Southern Taiga of North-Western European Russia (Andersson et al., 2009).

\# Skyttella mulleri (Willey) D. Hawksw. \& R. Sant. - ELR, Podporozhje District, ca. 4 km SSW of the village Yandeba, the Chaldoga River valley, $60^{\circ} 48^{\prime} 01^{\prime \prime} \mathrm{N}, 34^{\circ} 00^{\prime} 17^{\prime \prime} \mathrm{E}$, aspen-spruce forest with Convallaria majalis and Oxalis acetosella L., on Peltigera praetextata (Flörke ex Sommerf.) Zopf. on bark of Populus tremula, 23.07.2013, leg. IS (BILAS). - New to LR. Distribution in North-Western European Russia outside of LR: Republic of Karelia (Fadeeva et al., 2007). Distribution in Fennoscandia and Baltic countries: Norway, Sweden, Finland (Nordin et al., 2011).

Stereocaulon taeniarum (H. Magn.) Kivistö WLR, Ka, Vyborg District, the Gulf of Vyborg, Vyborgsky protected area, Mayachny Island, $60^{\circ} 34^{\prime} 24^{\prime \prime} \mathrm{N}, 28^{\circ} 25^{\prime} 30^{\prime \prime} \mathrm{E}$, moss-lichen community on rocks, and $60^{\circ} 34^{\prime} 25^{\prime \prime} \mathrm{N}, 28^{\circ} 25^{\prime} 24^{\prime \prime} \mathrm{E}$, seashore rocky outcrops with pines, both collected on soil, 11.09.2013, leg. DH, IS \& GT (LECB). Specimens contain atranorin and lobaric acid. - New to Russia. Distribution in Fennoscandia and Baltic countries: Sweden, Finland (Nordin et al., 2011), Lithuania (Motiejūnaitè et al., 2013). Separated from S. paschale (L.) Hoffm. by the absence of distinct cephalodia, by thick axis, few branchlets, and phyllocladia that cover the pseudopodetia all around; mainly with coastal distribution (Kivistö, 1998).

\# Stigmidium lePRARiae Zhurb. - WLR, Ka, Vyborg District, the Gulf of Vyborg, Vyborgsky protected area, Bol'shoy Lugovoy Island, $60^{\circ} 32^{\prime} 50^{\prime \prime} \mathrm{N}$, $28^{\circ} 33^{\prime} 32^{\prime \prime} \mathrm{E}$, birch-pine forest with Convallaria majalis, Vaccinium myrtillus and mosses, on thallus of Lepraria sp. on siliceous stone, 13.09.2013, leg. DH, IS \& GT (BILAS). - New to North-Western European Russia. Known from Murmansk Region (Zhurbenko, 2009a). Distribution in Fennoscandia and Baltic countries: Norway (Nordin et al., 2011). Recently described Stigmidium leprariae was known from the thalli of Lepraria neglecta group only (Zhurbenko, 2007a, 2009a; Kukwa \& Flakus, 2009). Present specimen is in accordance with the protologue (Zhurbenko, 2007a), with numerous black perithecia $50-80 \mu \mathrm{m}$ in diam., ascospores $11-13 \times$ 4-5 $\mu \mathrm{m}$, sole-shaped, guttulate, one-septate (no 2-3-septate spores were observed), slightly con- 
stricted at the septum, smooth-walled, colourless to pale grey olive. Vegetative hyphae were not apparent on the host granules, but thallus showed some slight discolouration where perithecia of the fungus were especially numerous.

\section{ACKNOWLEDGEMENTS}

We would like to thank colleagues at the Botanical Museum of University of Helsinki and lichen herbarium of University of Graz for their help during our investigations in $\mathrm{H}$ and GZU. The authors also appreciate the help of Ludmila V. Gagarina, Ekaterina S. Kuznetsova and Lilia V. Kuz'mina who participated in the field work in 2011-2013. Our warm thanks are due to J. Hafellner (Graz) for discussion on Agonimia, T. Ahti (Helsinki) for valuable comments on nomenclature of Cladonia macroceras, and to anonymous Reviewer for corrections to the manuscript. We are grateful to the staff of Metsäliitto Podporozh'e corporation for organizing the field trips to different districts of ELR, and Baltic Fund for Nature for organizing the field trip to the islands of Vyborgsky protected area. The study was financially supported by Russian Foundation for Basic Research (grant 14-04-01411), RSCF grant 14-24-00037, research grant 1.37.151.2014 of Saint Petersburg State University, the Program of Basic Research of the Presidium of RAS "Wildlife: Current Status and Problems of Development" and the Directorate of Nature Protected Areas of Saint Petersburg.

\section{REFERENCES}

Ahti, T. \& Stenroos, S. 2013. Cladonia. In: Ahti, T., Stenroos, S. \& Moberg, R. (eds), Nordic Lichen Flora 5: 8-87.

Andersson, L., Alexeeva, N. \& Kuznetsova, E. (eds). 2009. Survey of biologically valuable forests in North-Western European Russia. Vol. 2. Identification manual of species to be used during survey at stand level. St. Petersburg. (In Russian). 258 pp.

Aptroot, A., Diederich, P., Van Herk, C. M., Spiers L. \& Wirth, V. 1997. Protoparmelia hypotremella, a new sterile corticolous species from Europe, and its lichenicolous fungi. Lichenologist 29(5): 415-424. http://dx.doi.org/10.1017/S0024282997000509

Czarnota, P. \& Coppins, B. J. 2000. A new species of Agonimia and some interesting lichens from Gorce Mts (Western Beskidy Mts) new to Poland. Graphis Scripta 11: 56-60.
Eichler, M., Cezanne, R., Diederich, P., Ertz, D., Van den Broeck, D., van den Boom, P. \& Serusiaux, E. 2010. New or interesting lichens and lichenicolous fungi from Belgium, Luxembourg and northern France. XIII. Bulletin de la Société des naturalistes luxembourgeois 111: 33-46.

Etayo, J. \& Sancho, L. G. 2008. Hongos Liquenícolas del Sur de Sudamérica, Especialmente de Isla Navarino (Chile). Bibliotheca Lichenologica 98: 1-302.

Fadeeva, M. A., Golubkova, N. S., Vitikainen, O. \& Ahti, T. 2007. Conspectus of lichens and lichenicolous fungi of the Republic of Karelia. Karelian Research Centre of RAS, Petrozavodsk. (In Russian, English summary). 194 pp.

Hafellner, J. 1994. Beiträge zu einem Prodromus der lichenicolen Pilze Österreichs und angrenzender Gebiete. I. Einige neue oder seltene Arten. Herzogia 10: 1-28.

Himelbrant, D. E., Motiejūnaitè, J., Pykälä, J., Schiefelbein, U. \& Stepanchikova, I. S. 2013. New records of lichens and allied fungi from the Leningrad Region, Russia. IV. Folia Cryptogamica Estonica 50: 23-31. http://dx.doi.org/10.12697/ fce.2013.50.04

Ihlen, P. G. \& Wedin, M. 2008. An annotated key to the lichenicolous Ascomycota (including mitosporic morphs) of Sweden. Nova Hedwigia 86(3-4): 275-365. http://dx.doi.org/10.1127/00295035/2008/0086-0275

Kivistö, L. 1998. Taxonomy of Stereocaulon paschale and allied species in Finland. Sauteria 9: 25-36.

Kocourková, J., 2000. Lichenicolous fungi of the Czech Republic (The first commented checklist). Sbornik Národního Muzea v Prazĕ. Ǩada B: Přirodni Vědy 55: 59-169.

Kotiranta, H., Uotila, P., Sulkava, S. \& Peltonen, S.-L. (eds). 1998. Red Data Book of East Fennoscandia. Helsinki. 351 pp.

Kukwa, M. \& Flakus, A. 2009. New or interesting records of lichenicolous fungi from Poland VII: species mainly from Tatra Mountains. Herzogia 22: 191-211.

Kuznetsova, E., Ahti, T. \& Himelbrant, D. 2007. Lichens and allied fungi of the Eastern Leningrad Region. Norrlinia 16: 1-62.

Kuznetsova, E. S., Motiejūnaitè, J., Stepanchikova, I. S., Himelbrant, D. E. \& Czarnota, P. 2012. New records of lichens and allied fungi from the Leningrad Region, Russia. III. Folia Cryptogamica Estonica 49: 31-37.

Motiejūnaitè, J. 1999. Checklist of lichens and allied fungi of Lithuania. Botanica Lithuanica 5(3): 251-269.

Motiejūnaitè, J. \& Piterāns, A. 1998. Materials on lichens and allied fungi of Kemeri National Park (Latvia). Botanica Lithuanica 4(2): 187-196.

Motiejūnaitė, J., Brackel, W., Stončius, D. \& Preikša, Ž. 2011. Contribution to the Lithuanian flora of lichens and allied fungi. III. Botanica Lithuanica 17(1): 39-46. 
Motiejūnaitè, J., Czyzewska, K. \& Cieslinski, S. 2004. Lichens - indicators of old-growth forests in biocentres of Lithuania and north-east Poland. Botanica Lithuanica 10(1): 59-74.

Motiejūnaite, J., Kukwa, M., Lõhmus, P., Markovskaja, S., Oset, M., Prigodina-Lukošiene, I., Stončius, D. \& Useliene, A. 2013. Contribution to the Lithuanian flora of lichens and allied fungi. IV. Botanica Lithuanica 19(1): 3-7. http:/ / dx.doi.org/10.2478/ botlit-2013-0001

Motiejūnaite, J., Suija, A., Lõhmus, P., Kuznetsova, E., Tõrra, T., Prigodina-Lukošienè, I. \& Piterāns, A., 2006. New or noteworthy lichens, lichenicolous and allied fungi found during the 16th Symposium of Mycologists and Lichenologists in Latvia. Botanica Lithuanica 12(2): 113-119.

Nordin, A., Moberg, R., Tønsberg, T., Vitikainen, O., Dalsätt, Å., Myrdal, M., Snitting, D. \& Ekman, S. 2011. Santesson's Checklist of Fennoscandian Lichen-forming and Lichenicolous Fungi. Ver. April 29, 2011 - http://130.238.83.220/santesson/ home.php (27 March 2014).

Orange, A., James, P. W. \& White, F. J. 2001. Microchemical methods for the identification of lichens. British Lichen Society, London. 101 pp.

Piterāns, A. 2001. Checklist of the lichens of Latvia. Latvijas Vegetācila 3: 5-46.

Pykälä, J., Stepanchikova, I. S., Himelbrant, D. E., Kuznetsova, E. S. \& Alexeeva, N. M. 2012. The lichen genera Thelidium and Verrucaria in the Leningrad Region (Russia). Folia Cryptogamica Estonica 49: 45-57.

Randlane, T., Saag, A. \& Suija, A. 2013. Lichenized, lichenicolous and allied fungi of Estonia. Ver. December 31, 2013 - http://esamba.bo.bg.ut.ee/ checklist/est/home.php (20 March 2014).

Saag, L., Saag, A. \& Randlane, T. 2009. World survey of the genus Lepraria (Stereocaulaceae, lichenized Ascomycota). Lichenologist 41(1): 25-60. http:/ / dx.doi.org/10.1017/S0024282909007993

Sérusiaux, E., Diederich, P., Brand, A. M. \& van den Boom, P. P. G. 1999. New or interesting lichens and lichenicolous fungi from Belgium and Luxembourg. VIII. Lejeunia, N. S. 162: 1-95.

Sokolova, S. V. 1995. The genus Cladonia in the lichen flora of Leningrad Region. (In Russian). Novitates Systematicae Plantarum Non Vascularum 30: 90-93.

Stepanchikova, I. S., Himelbrant, D. E., Kukwa, M. \& Kuznetsova, E. S. 2011a. New records of lichens and allied fungi from the Leningrad Region, Russia. II. Folia Cryptogamica Estonica 48: 85-94.
Stepanchikova, I. S., Kukwa, M., Kuznetsova, E. S., Motiejūnaite, J. \& Himelbrant, D. E. 2010. New records of lichens and allied fungi from the Leningrad Region. Folia Cryptogamica Estonica 47: 77-84.

Stepanchikova, I. S., Kuznetsova, E. S. \& Himelbrant, D. E. 2009. New records of lichens and allied fungi from the Eastern Leningrad Region. Folia Cryptogamica Estonica 46: 75-78.

Stepanchikova, I. S., Schiefelbein, U., Alexeeva, N. M., Ahti, T., Kukwa, M., Himelbrant, D. E. \& Pykälä, J. 2011b. Additions to the lichen biota of Berezovye Islands, Leningrad Region, Russia. Folia Cryptogamica Estonica 48: 95-106.

Triebel, D. 1989. Lecideicole Ascomyceten. Eine Revision der obligat lichenicolen Ascomyceten auf lecideoiden Flechten. Bibliotheca Lichenologica 35: 1-278.

Urbanavichus, G. P. 2010. A checklist of the lichen flora of Russia. (In Russian). St. Petersburg, Nauka. 194 p.

Urbanavichus, G. P. \& Urbanavichene, I. N. 2010. Lichen flora. In: Mirkin B. M. (ed.). Flora and vegetation of Bashkiria National Park (syntaxonomy, anthropogenic dynamics, ecological zonation). (In Russian). Ufa, Gilem, pp. 65-78.

Urbanavichene, I. N., Urbanavichus, G. P., Mežaka, A. \& Palice, Z. 2013. New records of lichens and lichenicolous fungi from the Southern Ural Mountains, Russia. II. Folia Cryptogamica Estonica 50: 73-80. http://dx.doi.org/10.12697/ fce. 2013.50 .10

Zhurbenko, M. P. 2007a. New lichenicolous fungi from Eurasia. Graphis scripta 19: 1-9.

Zhurbenko, M. P. 2007b. The lichenicolous fungi of Russia: geographical overview and a first checklist. Mycologia Balcanica 4: 105-124.

Zhurbenko, M. P. 2009a. Lichenicolous fungi and some lichens from the Holarctic. Opuscula Philolichenum 6: 87-120.

Zhurbenko, M. P. 2009b. Lichenicolous fungi and some lichens from the Holarctic. Part II. Opuscula Philolichenum 7: 121-186.

Zhurbenko, M. P. \& Himelbrant, D. E. 2002. Lichenicolous fungi from the Kandalaksha Gulf, Karelia Keretina, Russia. Folia Cryptogamica Estonica 39: 51-59.

Zhurbenko, M. P. \& Zhdanov, I. S. 2013. Melaspilea galligena sp. nov. and some other lichenicolous fungi from Russia. Folia Cryptogamica Estonica 50: 89-99. http://dx.doi.org/10.12697/ fce.2013.50.12 
56 Folia Cryptog. Estonica 